Szkoła Główna Gospodarstwa Wiejskiego,

Wydział Nauk Ekonomicznych

tomasz_rokicki@sggw.pl

Magdalena GolONKO

Szkoła Główna Gospodarstwa Wiejskiego,

Wydział Nauk Ekonomicznych

magdalena.wiluk@gmail.com

ALEKSANDRA GÓRECKA

Szkoła Główna Gospodarstwa Wiejskiego,

Wydział Nauk Ekonomicznych

aleksandra_gorecka@sggw.pl

\title{
TRANSPORT NEEDS FOR AGRIBUSINESS SECTOR In Poland
}

\section{POTRZEBY TRANSPORTOWE SEKTORA Agrobiznesu W Polsce}

\begin{abstract}
Transport is said to be an activity that supports and influence the economic development. Depending on the production sectors in the country, the transport volume varies between different products and raw materials.

The main aim of the paper was to indicate correlation between the economic situation in Poland and the volume of transport of agribusiness sector products. Pearson's linear correlation was used for this analysis.

The research results indicated that since 2005 the demand for road transport of products from the agribusiness sector has grown faster than in other cargo groups. The share of this type of cargo in total transport is growing and is higher than the average for total products. At the same time, the relationship between the volume of transport and economic indicators is very strong.
\end{abstract}

\section{STRESZCZENIE}

Transport jest działalnością, która niewątpliwie wspiera rozwój gospodarki. W zależności od działów produkcji w kraju, wolumen transportu jest różny dla poszczególnych produktów oraz surowców. 
Celem głównym artykułu było wskazanie zależności między sytuacją gospodarczą w Polsce a wolumenem przewozów produktów sektora agrobiznesu. Do analizy wykorzystano korelację liniową Pearsona.

Wyniki badań wskazały, że popyt na przewóz samochodowy produktów z sektora agrobiznesu rósł szybciej niż w przypadku innych grup ładunków, o czym świadczył rosnący udział tego typu ładunków w przewozach ogółem oraz wyższa od średniej dla produktów ogółem, dynamika wzrostu. Jednocześnie zależność między wolumenem przewozu a wskaźnikami gospodarczymi była bardzo silna.

KEYWORDS: transport, agribusiness, GDP, correlation, economic sectors

SŁOWA KLUCZOWE: transport, agrobiznes, PKB, korelacja, sektory ekonomii

\section{WPROWADZENIE}

Transport jest jednym z najważniejszych czynników wpływających na wielkość handlu i wzrost gospodarczy. Sieć transportowa natomiast jest uważana za trzon łańcucha dostaw, który z kolei umożliwia efektywną dystrybucję towarów i zwiększa ich dostępność na odległych rynkach (Krugman, 1991, s. 75-84). Wielu autorów wskazuje, że transport jest sektorem, który stanowi trzon gospodarek krajowych czy wspólnotowych (Prud'homme, 2002, s. 81-98; Vickerman 2008, s. 31-48; Górecka, Rokicki, 2013, s. 2; Mindur, 2005, s. 3-6). Rozwój gospodarczy jest zwykle poprzedzany rozwojem transportu, który przybliża rynki zaopatrzeniowe, w tym surowcowe. Niewystarczająca podaż usług transportowych może uniemożliwić uruchomienie pozyskania zasobów naturalnych, czyniąc zbyt kosztowną szeroką specjalizację i kooperację produkcji (Grzywacz i Brunewicz, 1989, s. 41). Transport umożliwia więc wymianę dóbr i usług poprzez przewóz surowców, materiałów i półfabrykatów przeznaczonych do produkcji oraz gotowych produktów przeznaczonych do konsumpcji (Rydzkowski i Wojewódzka-Król, 2009, s. 1-25).

Wydaje się zatem, że wolumen przewozu produktów wytworzonych w danym regionie powinien odzwierciedlać sytuację gospodarczą tego obszaru. Zdania na ten temat są jednak podzielone. Rydzkowski (2000, cyt. za: Mindur, 2005, s. 9) twierdzi, że proporcja między wykonywanymi przewozami a wielkością produkcji jest odzwierciedleniem komplementarności transpor- 
tu względem gospodarki. Mindur (2005, s. 9-10) wskazuje jednocześnie, że przy wzrastającej produkcji następuje zmniejszanie się przewozów, ale nie traktuje takiego zjawiska, jako negatywnego, tłumacząc, że taka relacja oznaczać może odchodzenie gospodarki od produkcji surowcowej. Ciekawe stanowisko przedstawiają Burnewicz i Szczerba (2004, s. 8) twierdząc, że duża i stale wzrastająca skala działalności transportu w normalnie funkcjonującej gospodarce nie jest zjawiskiem pozytywnym, gdyż przyczynia się do wzrostu kosztów: operacji przestrzennych, produkcji i dystrybucji oraz cen towarów. Autorzy zaznaczają, że dla gospodarki najważniejsza jest wielkość wartości dodanej tworzonej w sektorze transportu, a nie fizyczna masa przewozów lub praca przewozowa. W gospodarkach opartych na wiedzy i wysokich technologiach maleje popyt na surowce i materiały, co pociąga za sobą zmniejszenie popytu na przewozy.

Można więc przyjąć, że zależności od specjalizacji sektorowej kraju, wielkości przewozowe różnych produktów będą różniły się między sobą. I tak na przykład, w gospodarce opartej na produkcji rolniczej i szeroko pojętym agrobiznesie, znaczną uwagę powinno poświęcać się badaniom przewozów produktów spożywczych, zarówno z punktu widzenia efektywności samego procesu transportowego, bezpieczeństwa transportu produktów nietrwałych, jak też związków wolumenu transportu z sytuacją gospodarczą.

Badania dotyczące transportu płodów rolnych i produktów żywnościowych obejmują różne zagadnienia ze względu na ich kompleksowy, dynamiczny oraz wrażliwy charakter. Zarówno surowce, jak i wyroby gotowe sektora agrobiznesu mają specyficzny charakter (Baran, 2012, s. 827-830) ze względu na wzrastającą złożoność operacyjną (Lorenc, 2014, 655), dynamiczne zmiany wynikające $\mathrm{z}$ zaspokojenia potrzeb konsumentów (Górecka i Zych-Lewanowska, 2016, s. 53-54; Górecka i in. 2017, s. 1817-1819; Parlińska i in., 2012), nowe regulacje prawne (Krzewińska i Matysek, 2012, s. 240) oraz krótki okres trwałości produktu (Gajewska, 2014, s. 3716-3717; Farahani i in., 2012, s. 28-30).

Niewiele jest jednak publikacji dotyczących związku między wolumenem przewożonych produktów sektora agrobiznesu a sytuacją gospodarczą kraju. W rezolucji Parlamentu Europejskiego (Logistyka transportu towarowego..., 2006, s. 8) podkreślono znaczenie minimalizacji potrzeb transportowych 
płodów rolnych i produktów spożywczych. Strukturę przewozu produktów agrobiznesu przedstawił Klepacki (2013, s. 14-17), wskazując, że transportowany wolumen jest porównywalny z pozostałymi produktami gospodarki. Problem efektywnej organizacji transportu produktów sektora agrobiznesu podkreśla też Rokicki (2013, s. 116-118).

\section{Cele I METOdy BADAWCZE}

Celem głównym artykułu było przedstawienie zmian wolumenu przewozów ładunków sektora agrobiznesu w Polsce w latach 2005-2016 oraz wskazanie związku tych wielkości z sytuacją gospodarczą kraju. Autorzy postawili następującą hipotezę badawczą:

H1: Istnieje silna liniowa zależność pomiędzy wolumenem przewożonych produktów z sektora agrobiznesu a sytuacją gospodarczą w Polsce.

Do badań wykorzystano źródła wtórne, do których należą przede wszystkim opracowania i dane statystyczne Głównego Urzędu Statystycznego oraz krajowa i międzynarodowa literatura przedmiotu. Badania dotyczyły lat 2005-2016.

Do analizy zgromadzanych danych wykorzystano współczynnik korelacji liniowej Pearsona wyrażony wzorem (Stanisławek, 2010, s. 78-80):

$$
r_{x y}=\frac{\sum_{i=1}^{n}\left(x_{i}-\bar{x}\right)\left(y_{i}-\bar{y}\right)}{\sqrt{\sum_{i=1}^{n}\left(x_{i}-\bar{x}\right)^{2}} \sqrt{\sum_{i=1}^{n}\left(y_{i}-\bar{y}\right)^{2}}}
$$

W badaniach analizowano dwie grupy ładunków:

$\mathrm{x}_{1}$ - produkty rolnictwa, łowiectwa, leśnictwa, rybactwa i rybołówstwa,

$\mathrm{x}_{2}$ - produkty spożywcze, napoje i wyroby tytoniowe.

Za parametry gospodarcze przyjęto natomiast:

$\mathrm{y}_{1}$ - wartość PKB,

$\mathrm{y}_{2}-\mathrm{PKB}$ per capita,

$\mathrm{y}_{3}$ - wartość dodana brutto, 
$\mathrm{y}_{4}$ - wartość popytu krajowego,

$\mathrm{y}_{5}$ - wartość konsumpcji gospodarstw domowych,

$\mathrm{y}_{6}$ - wartości eksportu,

$\mathrm{y}_{7}$ - wartość importu.

Jako wartość graniczną poziomu istotności przyjęto $\mathrm{p}=0,05$.

\section{WYNIKI BADAŃ}

W latach 2005-2016 ładunki w Polsce były przewożone głównie transportem samochodowym (rys. 1). Udział tej gałęzi transportu, pod względem wolumenu przewożonych ładunków w tonach, wzrósł z 75,9\% w 2005 roku do 83,22\% w 2016 roku. Przy czym trzeba podkreślić, że już w 2012 roku został osiągnięty poziom $83 \%$ i od tego momentu nie zmieniał się w kolejnych latach. Wydaje się, że nastąpiło już nasycenie rynku tego rodzaju przewozami, a w innych gałęziach transportu są przewożone ładunki predysponowane do taniego przewozu, jak np. towary masowe w postaci węgla kamiennego, rud metali itp. Przedstawione zestawienie świadczy o dużym znaczeniu transportu samochodowego w Polsce. Prawdopodobnie w kolejnych latach nie będą już zachodziły żadne znaczące zmiany w strukturze przewozów ładunków według gałęzi transportu.

Rysunek 1.

Struktura przewozów ładunków w Polsce według gałęzi transportu w latach 2005-2016

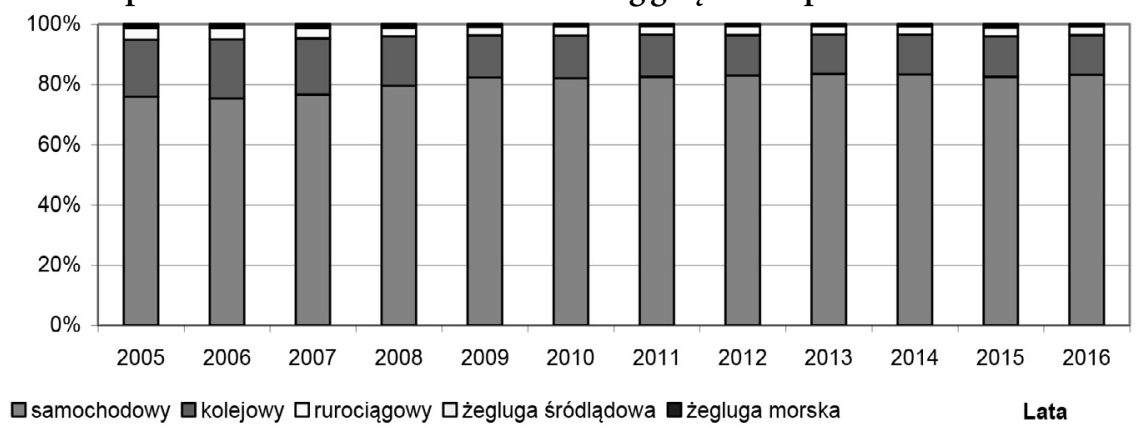

Źródło: opracowanie własne na podstawie danych GUS.

Produkty spożywcze były ważnym towarem dla klientów, o czym świadczy ich udział w strukturze wydatków gospodarstw domowych (rys. 2). 
W 2005 roku na żywność i napoje bezalkoholowe przeciętnie przeznaczano $21,1 \%$ wszystkich wydatków, a na napoje alkoholowe i wyroby tytoniowe 7,1\%. W 2016 roku było to odpowiednio 17,1\% i 5,8\%. Udział względny wydatków na produkty żywnościowe zmniejszał się, co jest naturalnym zjawiskiem. Wraz z bogaceniem się społeczeństwa przeznaczano procentowo coraz mniej środków na żywność. Nie oznacza to, że mniej wydawano na żywność, a wręcz przeciwnie. W latach 2005-2016 nastąpił bowiem wzrost wydatkowanych kwot pieniężnych przez gospodarstwa domowe. Popyt na żywność rósł, ale w mniejszym stopniu niż wydatki całkowite. Niemniej udział wydatków na wszelkiego rodzaju produkty żywnościowe był ciągle bardzo duży, co powodowało zgłaszanie znaczącego popyt na transport, który powinien dostarczyć produkty do miejsc ich nabycia i konsumpcji. Co ciekawe, w badanym okresie, wzrósł udział wydatków gospodarstw domowych na transport z 10,2\% w 2005 do 12,0\% w 2016 roku.

\section{Rysunek 2.}

Udział wydatków na produkty spożywcze w całkowitych wydatkach gospodarstwach domowych w latach 2005-2016

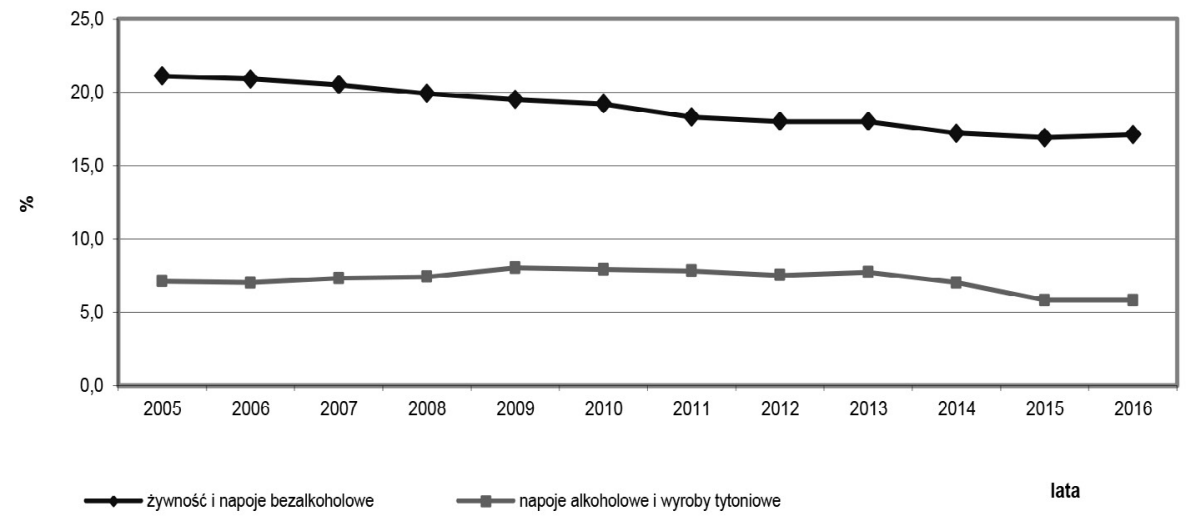

Źródło: opracowanie własne na podstawie danych GUS.

Produkty żywnościowe były przewożone głównie transportem samochodowym. W przypadku pozostałych gałęzi, wolumen przewozów tego typu ładunków był mały. W związku z tym w artykule autorzy skoncentrowali się jedynie na transporcie samochodowym. 
Analizując dane statystyczne publikowane przez GUS, można znaleźć dwie grupy produktów, które są domeną sektora agrobiznesu. Pierwszą z nich są produkty rolnictwa, łowiectwa, leśnictwa, rybactwa i rybołówstwa, których udział w wolumenie przewożonych ładunków transportem samochodowym wzrósł z 3,9\% w 2005 roku do 7,7\% w 2016 roku (rys. 3). W drugiej grupie, zawierającej produkty spożywcze, napoje i wyroby tytoniowe, również nastąpił wzrost udziału z 9,7\% w 2005 roku do 10,7\% w 2016 roku. Trzeba też podkreślić, że w badanym okresie przewozy samochodowe ogółem wzrosły o 52\%, w tym produktów rolnictwa z pierwszej grupy aż o $200 \%$, zaś produktów spożywczych z drugiej grupy o 67\%. Tempo wzrostu przewozów produktów z sektora agrobiznesu było więc szybsze niż w pozostałych grupach ładunków. Świadczy to o rosnących potrzebach tego sektora w Polsce i coraz większym wykorzystaniu transportu samochodowego. Dlatego też konieczne są działania mające na celu lepsze zarządzanie transportem w przedsiębiorstwach, jak i w ujęciu całego systemu na poziomie makro.

Rysunek 3.

Udział wolumenu przewiezionych produktów rolniczych i produktów spożywczych w przewozach towarów ogółem transportem samochodowym w latach 2005-2016

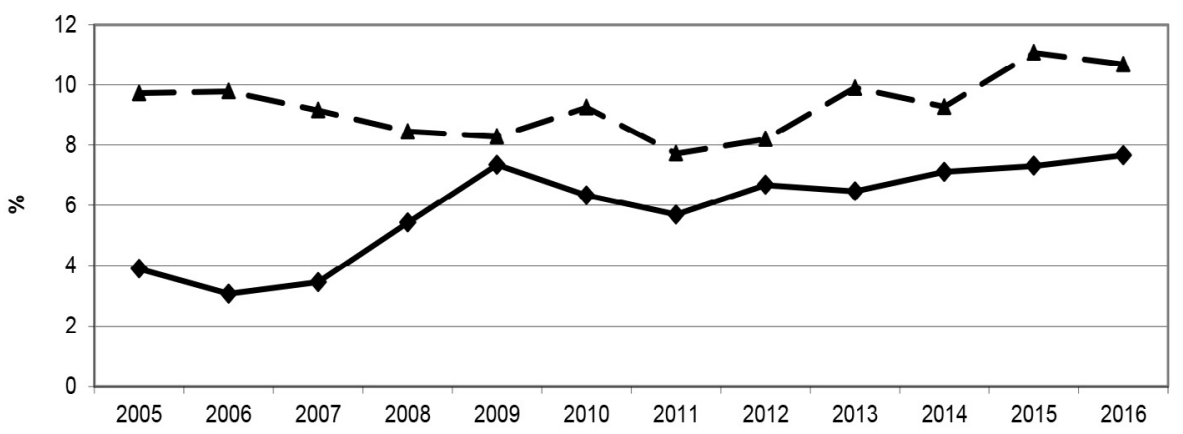

Produkty rolnictwa, łowiectwa, leśnictwa, rybactwa i rybołówstwa

lata

Źródło: opracowanie własne na podstawie danych GUS.

W latach 2005-2016 nastąpił też wzrost średniej odległości transportowej w przewozach samochodowych ze $130 \mathrm{~km}$ do $228 \mathrm{~km}$. W przypadku produktów rolnictwa, łowiectwa, leśnictwa, rybactwa i rybołówstwa odnotowano 
wzrost z 168 do $362 \mathrm{~km}$ (podwojenie odległości), a produktów spożywczych, napoi i wyrobów tytoniowych z 194 do 277 km. Taki wynik oznacza spełnianie przez przewozy samochodowe już nie tylko roli zaopatrzeniowej dla lokalnych rynków, ale również dla rynków krajowych i międzynarodowych. Produkty $\mathrm{z}$ sektora agrobiznesu $\mathrm{z}$ uwagi na swoją specyfikę wymagają szybkiego dostarczenia na czas. Taką funkcję gwarantuje transport samochodowy.

\section{Rysunek 4.}

Dynamika zmian wolumenu przewiezionych produktów rolniczych i produktów spożywczych w latach 2005-2016 (rok poprzedni $=100)$

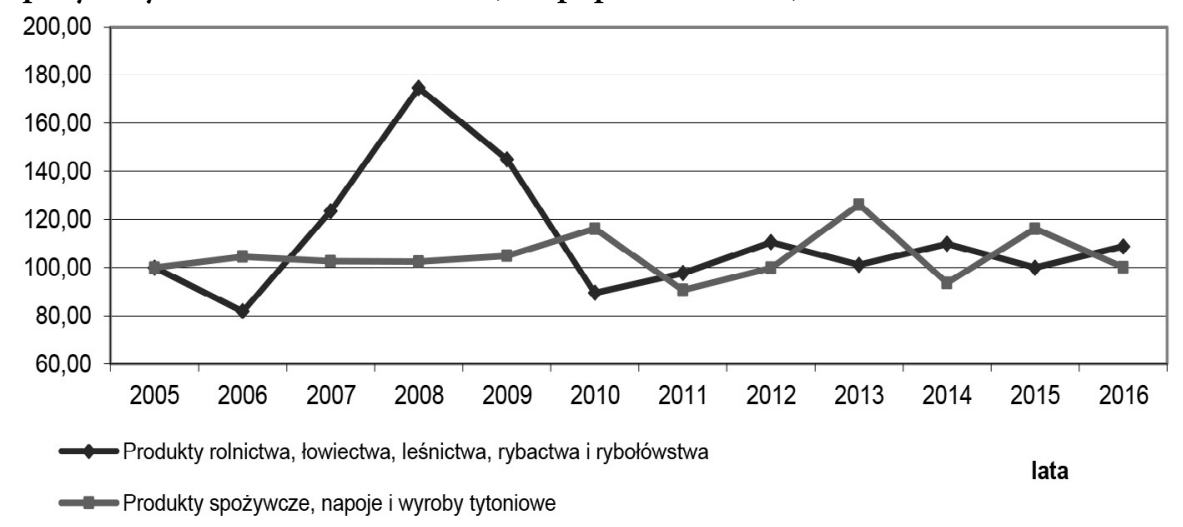

Źródło: opracowanie własne na podstawie danych GUS.

Obliczono również wskaźniki dynamiki łańcuchowej dla dwóch grup towarów obsługiwanych przez sektor agrobiznesu (rys. 4). Pozwoliło to na wskazanie lat, w których następowały szczególne zmiany w wolumenie przewożonych ładunków transportem samochodowym. Z reguły występowały zwiększenia przewozów. W przypadku produktów rolnictwa największy przyrost przewozów odnotowano w 2008 roku (o 75\%), a w dalszej kolejności w 2009 roku, który był związany z kryzysem gospodarczym (o 45\%). Spadki przewozów, jeżeli już występowały, to były mniejsze (największy był w 2006 roku o 18\%). W drugiej grupie zawierającej produkty spożywcze wahania były mniejsze. Największy wzrost przewozów odnotowano w 2013 roku (o 26\%), zaś spadek w 2011 roku (o 9\%). Przedstawione zestawienie pokazuje, że wzrost przewozów ładunków z sektora agrobiznesu nie następował 
ciągle, występowały wahania spowodowane różnymi czynnikami, najczęściej gospodarczymi. Zarówno zaopatrzenie przetwórstwa spożywczego, jak i dystrybucja wytworzonych produktów są warunkowane sytuacją gospodarczą.

Tabela 1.

Współczynniki korelacji liniowej Pearsona między parametrami gospodarki a wolumenem przewożonych ładunków $\mathrm{z}$ sektora agrobiznesu

\begin{tabular}{|c|c|c|c|c|}
\hline \multirow{2}{*}{ Parametry } & \multicolumn{4}{|c|}{ Współczynniki korelacji liniowej Pearsona } \\
\cline { 2 - 5 } & \multicolumn{2}{|c|}{$\mathbf{x}_{1}$} & \multicolumn{2}{|c|}{$\mathbf{x}_{2}$} \\
\cline { 2 - 5 } & $\mathbf{r}$ & p-value & $\mathbf{r}$ & p-value \\
\hline $\mathrm{y}_{1}$ & 0,920 & 0,001 & 0,908 & 0,001 \\
\hline $\mathrm{y}_{2}$ & 0,931 & 0,001 & 0,886 & 0,001 \\
\hline $\mathrm{y}_{3}$ & 0,921 & 0,001 & 0,909 & 0,001 \\
\hline $\mathrm{y}_{4}$ & 0,909 & 0,001 & 0,879 & 0,001 \\
\hline $\mathrm{y}_{5}$ & 0,949 & 0,001 & 0,885 & 0,001 \\
\hline $\mathrm{y}_{6}$ & 0,837 & 0,001 & 0,933 & 0,001 \\
\hline $\mathrm{y}_{7}$ & 0,808 & 0,001 & 0,887 & 0,001 \\
\hline
\end{tabular}

Źródło: opracowanie własne.

Stwierdzono bardzo silne istotne dodatnie korelacje między sytuacją gospodarki a wolumenem przewozów ładunków z sektora agrobiznesu transportem samochodowym (tab. 1). Przedstawione wyniki korelacji wskazują na silne powiązanie przewozów produktów rolniczych i spożywczych z sytuacją gospodarczą. Dla produktów rolniczych największa siła oddziaływania była w przypadku wartości konsumpcji gospodarstwa domowych, zaś najmniejsza w odniesieniu do wartości importu. Może to oznaczać mniejsze uzależnienie sektora agrobiznesu od importu płodów rolnych (co jest związane z lokalnym zaopatrzeniem przetwórstwa) oraz duży związek z wydatkami gospodarstw domowych. Przewóz produktów spożywczych był najbardziej współzależny z wartością eksportu, a najmniej z wartością konsumpcji gospodarstw domowych, co z kolei oznacza duże uzależnienie od sprzedaży wyrobów gotowych na rynki zagraniczne. 


\section{Podsumowanie}

Sektor agrobiznesu zgłasza duże zapotrzebowanie na przewóz płodów rolnych, jak również przetworzonych produktów spożywczych. Produkty żywnościowe stanowiły znaczący udział w wydatkach gospodarstw domowych, co powoduje duże znaczenie przewozów tego rodzaju ładunków. W Polsce dominował transport samochodowy, a udział pozostałych gałęzi przewozu był mały. Taka struktura miała swoje odzwierciedlenie również w przewozie ładunków zaopatrujących sektor agrobiznesu, jak i wyrobów finalnych będących efektem przetwórstwa żywności.

Popyt na przewóz samochodowy produktów z sektora agrobiznesu rósł szybciej niż w przypadku innych grup ładunków, o czym świadczy rosnący udział tego typu ładunków w przewozach ogółem oraz wyższa od średniej dla produktów ogółem, dynamika wzrostu. Stwierdzono również bardzo silne powiązania wolumenu przewozów samochodowych z sytuacją gospodarczą. Dobra koniunktura sprzyjała zwiększeniu wolumenu przewozów ładunków z sektora agrobiznesu. Przewóz produktów rolnictwa był bardziej związany z sytuacja wewnątrzkrajową, a transport produktów spożywczych z eksportem towarów poza granice państwa. Transport żywności wymaga w wielu wypadkach zastosowania specjalnych warunków, dzięki którym produkty zachowują swoje właściwości. Oprócz łatwych do zmierzenia potrzeb ilościowych należy więc zapewnić odpowiednie standardy jakościowe. Przedsiębiorstwa transportowe muszą stosować odpowiednie rozwiązania pozwalające na zarządzanie transportem produktów żywnościowych. Oprócz standardowych systemów, konieczne jest zastosowanie dedykowanych rozwiązań, np. w zakresie kontrolowania atmosfery podczas przewozu, szybkości w zamawianiu środków transportu lub elastyczności dostaw. Takie potrzeby wymagają odpowiedniej organizacji i zarządzania transportem. 


\section{Literatura}

Baran, J. (2012). Organizacja transportu $w$ wybranych branżach agrobiznesu, „Logistyka" nr 4, s. 827-835. ISSN 1231-5478.

Burnewicz, J., Szczerba, E. (2004), Nowa jakość polskiego transportu po integracji $z$ EU. „Przegląd Komunikacyjny” nr 10, s. 3-11. ISSN 0033-2232.

Farahani, P., Grunow, M., Günther, H-O. (2012). Integrated production and distribution planning for perishable food products. "Flexible Services and Manufacturing Journal”, nr 24 (1), s. 28-51. ISSN 1936-6582.

Gajewska, T. (2014). Analiza transportu produktów żywnościowych. „Logistyka” nr 6, s. 3716-3724. ISSN 1231-5478.

Górecka, A., Nowakowska, M., Tubis, A. (2017). Vulnerability assessment of passenger transport system-case study. Reliability and safety: innovating theory and practice, 26th Conference on European Safety and Reliability (ESREL), Glasgow, Sep 25-29, 2016, s. 1817-1823. ISBN 9781138029972.

Górecka, A., Rokicki, T. (2014). The significance of transportation in agribusiness companies. CLC 2013: Carpathian Logistics Congress - Congress proceedings, Dec 9-11, 2013, Cracow, Ed. Tanger Ltd. s. 24-30. ISBN 9788087294505.

Górecka, A., Zych-Lewandowska, M. (2016). Od producenta do konsumenta: determinanty transportu żywności w XXI wieku. Ekonomika i Organizacja Logistyki, nr 1 (1), s. 53-63. ISSN 2543-8867.

Grzywacz, W., Burnewicz, J. (1989). Ekonomika transportu, Warszawa: Wydawnictwo Naukowe PWN. ISBN 8320608163.

Klepacki, B., (2013). Concept and importance of agrologistics for development of agribusiness. Carpathian Logistics Congress - Congress Proceedings, Conference: Carpathian Logistics Congress (CLC), Cracow, Dec 09-11, 2013, Tanger Ltd, 14-17. ISBN 9788087294505.

Krugman, P. (1991). Geography and trade, The MIT Press, Cambridge. ISBN 9780262111591.

Krzewińska, A., Matysek, K. (2012). Wymagania stawiane środkom transportu żywności. „Autobusy: Technika, Eksploatacja, Systemy Transportowe” nr 5, s. 240-246. ISSN 1509-5878.

Logistyka transportu towarowego w Europie - klucz do zrównoważonej mobilności (2006). Komunikat Komisji do Rady, Parlamentu Europejskiego, Europejskiego Komitetu Ekonomiczno-Społecznego i Komitetu Regionów, Bruksela, 28.6.2006 r. 
Lorenc, A. (2014). Bezpieczeństwo i efektywność drogowego przewozu ładunków w relacji Polska - Rosja - wykorzystanie analizy AHP do wyboru trasy przejazdu. „Dokonania Młodych Naukowców", t. 4, s. 655-660. ISSN 2300-4436.

Mindur, M., (2005). Wzajemne relacje między gospodarka a transportem, „LogForum", t. 1, wyd. 1, nr 6, s. 1-12. ISSN 1895-2038.

Parlińska, M., Górecka, A., Misiejuk, M. (2012). Transportation service satisfaction - case study of shipping contractor of "Agro -Fish" company, "Electronic Journal of Polish Agricultural Universities", t. 15, wyd. 3. ISSN 1505-0297.

Prud'homme, R. (2002). Transport and economic development, "Report of the 109 Round Table on Transport Economics", ECMT, Paris. ISBN 9282112985.

Rokicki, T. (2013). The importance of logistics in agribusiness sector companies in Poland. "Economic Science for Rural Development", wyd. 30, s. 116-120. ISSN 16913078 .

Rydzkowski, W., Wojewódzka-Król, K. (2009). Transport, Warszawa: Wydawnictwo Naukowe PWN. ISBN 9788301195878.

Stanisławek, J. (2010). Podstawy statystyki. Opis statystyczny, korelacja i regresja, rozkłady zmiennej losowej, wnioskowanie statystyczne. Warszawa: Oficyna Wydawnicza Politechniki Warszawskiej. ISBN 9788372078827.

Vickerman, R. (2008). Recent evolution of research into the wider economic benefits of transport, Infrastructure investments, by the wider economic benefits of transport. Macro-, meso- and microeconomic transport planning and investment tools, "Report of the 140 Round Table on Transport Economics", OECD/ITF, Paris. ISSN 20708270. 